\title{
https://doi.org/10.46344/JBINO.2020.v09i05.20
}

\section{A CLINICAL STUDY OF TRUSHANADI CHURNA IN THE MANAGEMENT OF STHOULYA WITH SPECIAL REFERENCE TO OBESITY}

\author{
Bhairav Tawshikar ${ }^{1 *}$ Sanjeev Lokhande ${ }^{2} \&$ Shivaji Dhivare ${ }^{3}$ \\ 1. Associate Professor, Ashvin Rura Ayurved College,Manchihill,Maharashtra, India \\ 2. Professor, Kayachikitsa, Ashvin Rural Ayurved College, Manchihill. \\ 3. PG Scholar, ARAC Ayurved College, Ahmednagar, Maharashtra, India
}

Email :dr.bhairav@rediffmail.com

\begin{abstract}
A sedentary lifestyle, lack of physical activity, irregular diet and sleep pattern, stress are the causes of sthoulya i.e. obesity. Obesity is one of the nutritional lifestyle disorders affecting whole world.Sthoulyais such a disease, which provides the platform for so many complications like Hypertension, Diabetes Mellitus, Osteo-arthritis, infertility, impotency as well as psychological disturbances like stress, anxiety, depression etc. Hence prevention of obesity will decrease the chances of such disease. Environmental, lifestyle and genetic factors play an equally important role in its etiology.Inspite of advanced technology and researches in modern medical science its management aspect remains symptomatic with troublesome side effects. On the light of above, present study is carried out to know effective Ayurvedic treatment for Sthoulya i.e. Obesity.
\end{abstract}

Keywords: Sthoulya; Obesity; Trushanadi churna 


\section{INTRODUCTION}

Ayurveda is a science of life (1) firmly believes in "Swasthasya Swasthya Rakshanam Atursyavikar prashanam". Ayurveda is a science for both healthy as well as diseased person and it deals with prevention as well as cure of diseases (2). The World Health Organization (WHO) defines good health as a state of complete physical, mental \& social well being \& not merely an absence of disease or infirmity (3) which is in close proximity to the definition of good health mentioned in the ayurvedic classics. In Ayurveda Sthoulya has been described since very early days in various Samhitas, Sangrahgranthas, Nighantu etc. As charak has described sthoulya is one among the eight Ashtonindithas

(4) Santarpanjanyarog (5). In pathogenesis of Sthoulya Kapha, Vata \& Meda (6,7) are main responsible factors. According to Charak, Sthoulya is counted as a KaphaNanatmajVikar(8).

The main pathological factor is vitiated Kapha. According to Vagbhata Agnimandya at Jatharagni and Dhatwagni level is considered as root cause of all diseases (9). According to Sushruta rasa is responsible for Sthoulya (10). Rasa is the main nutritive pool which carries nutrients of all dhatu. Similarly the nutrients of Sthayi and Asthayi Medadhatu are transported through Rasadhatu. Sthoulya has become a burning problem of today's era caused by unwholesome dietary habits. It is a blessing of the Modern age of Machines and Materialism. It is estimated by WHO globally over 1 billion (16\%) adults are overweight and 100 million of these (5\%) are Obese(11)According to the National Family Health Survey (NFHS), the percentage of women aged 15-49 years who are overweight or obese increased from $12.6 \%$ in NFHS- 3 to $20.6 \%$ in NFHS-4 \& percentage of men aged $15-49$ years who are overweight or obese increased from 9.3\% in NFHS-3 to $18.9 \%$ in NFHS-4. Under nutrition is more prevalent in rural areas, whereas overweight and obesity are more than three times higher in urban areas. This may be due to lesser physical activity in the urban areas. Furthermore, under nutrition and overweight/obesity are both higher for women than men (12). "Sthoulya" (obesity) is such a disease, which provides the platform for so many complications like Hypertension, Diabetes Mellitus, Osteoarthritis, infertility, impotency as well as psychological disturbances like stress, anxiety, depression etc (13). Thus, the mortality and morbidity are more in obese person compared to others. It is one of the disease which is gaining more and more attention of scientists at global level. Many institutions and medical schools aremaking efforts to find a perfect remedy for this burning problem. Many theories have been put forward with many new hypothesis describing this disorder in Ayurveda as well as in modern science. Still there is enough scope to work out on its aetiopathological and management aspect. Because in modern medical science its management aspect remains symptomatic with troublesome side effects. 
On the light of above, present study has been selected.

\section{Objective of the study -}

To study the efficacy of Trushanadi Churna in the management of Sthoulya (Obesity).

\section{Case report-}

A 38 years old male patient reported to the Ashvin rural ayurvedic hospital, manchi hill, sangamner. With complaints Udarpradeshi Medovrudhhi, AayasenShwas, Daurbalya, Atiswedapravruti, Chalasphika, Chalauadaran Since 7 months. For that he had taken treatment of allopathy medicine for few days but don't get relief then he visited to kayachikitsa OPD for further management. Patient was thoroughly examined and detailed history was taken.

\section{Material and Methods-}

In the present study following drug were utilized.

Trushanadi Churna-
Ingredients(14)

-Trishan(Trikatu)

- Triphala

- Chavya

- Chitrak

- Vida

- Audbhida

- Bakuchi

- Saindhar

- Souvarchala

\section{Method of Preparation-}

Trushaadichurna was prepared as per the guidelines given by Bhaishajyaratnavali.

\section{Administration of drug-}

- Trushanadichurna was given $9 \mathrm{gm}$ in two equal dived doses with anupanghrut and madhu for 45 days.

- NidanParivarjana 
Diet Plan-

\begin{tabular}{|l|l|}
\hline Cereals & Jwari, Wheat roti or bhakri. \\
\hline Pulses & $\begin{array}{l}\text { Mudg dal, toor dal, Chana dal, } \\
\text { Masur dal. }\end{array}$ \\
\hline Vegetables & $\begin{array}{l}\text { Val, gawar, shigru, cauliflower, } \\
\text { cabbage, ghosale, dodke, karela. }\end{array}$ \\
\hline Liquids & $\begin{array}{l}\text { Takra, lemon water, Ushnodaka, } \\
\text { black tea, green tea, lemon tea } \\
\text { less oil (not more than 15 gm per } \\
\text { day). }\end{array}$ \\
\hline Exercise & $\begin{array}{l}\text { 45 min of brisk Waking or Cardio } \\
\text { exercise daily. }\end{array}$ \\
\hline Meals & $\begin{array}{l}\text { Only take meals twice a day. } \\
\text { (morning 9-1 \& evening 6-8) in } \\
\text { between do not consume any } \\
\text { food, if hungry u can drink above } \\
\text { said and lahi, murmura, popcorn. }\end{array}$ \\
\hline Other & $\begin{array}{l}\text { Do not sleep at daytime, Avoid } \\
\text { sedentary work for longer time. }\end{array}$ \\
\hline
\end{tabular}

Result-

Table 1: Effect of treatment of Trushanadichurnaon various assessment criteria (symptoms).

\begin{tabular}{|l|l|}
\hline Followup & Symptoms \\
\hline On $1^{\text {st }}$ day & UdarpradeshiMedovrudhhi ++++ \\
& AayasenShwas+++ \\
& Daurbalya+++ \\
& Atiswedapravruti++++ \\
& Chalasphika+++ \\
& Chalauadara+++ \\
\hline On $15^{\text {th }}$ day & UdarpradeshiMedovrudhhi++++ \\
& AayasenShwas++ \\
& Daurbalya++ \\
& Atiswedapravruti+++ \\
& Chalasphika +++ \\
& Chalauadara+++ \\
\hline
\end{tabular}

2020 September Edition | www.jbino.com | Innovative Association 


\begin{tabular}{|l|l|}
\hline On 30th day & UdarpradeshiMedovrudhhi +++ \\
& AayasenShwas+ \\
& Daurbalya+ \\
& Atiswedapravruti++ \\
& Chalasphika++ \\
& Chalauadara++ \\
\hline On 45th day & UdarpradeshiMedovrudhhi+ \\
& Chalasphika+ \\
& Chalauadara+ \\
& \\
\hline
\end{tabular}

Table 2: Effect of treatment of Trushanadichurnaon various objective criteria.

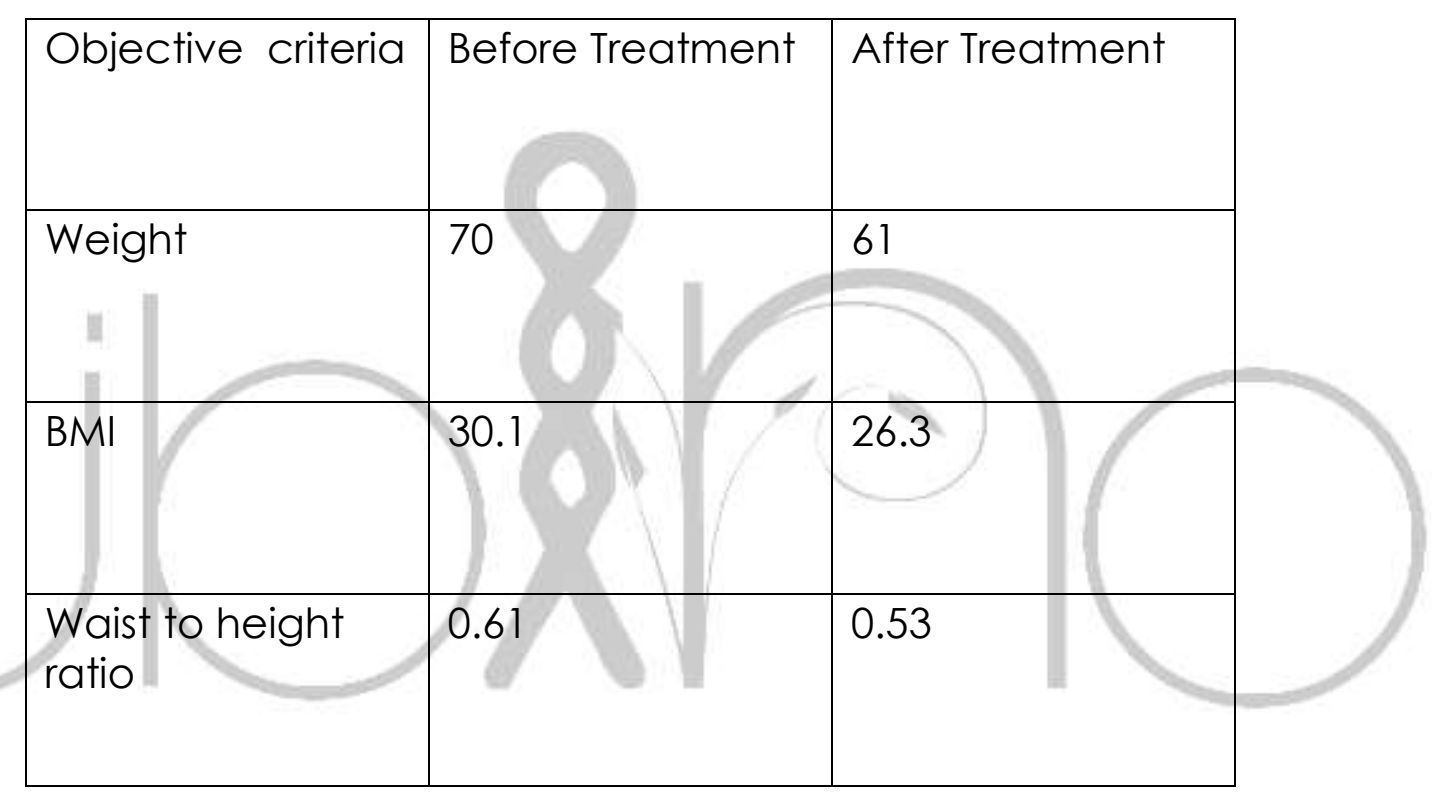

\section{DISCUSSION}

Aacharya Charakahas quoted Sthoulya under the eight varieties of impediments Which designated as Ashtau-Nindita Purusha. In Charak Samhita Sthoulya is described as santar panjanya vyadhi for which Apatarpan Chikitsa has been stated (15).In the pathogenesis of Sthoulyaboth Kaphaand Vataare vitiated along with Medodhatvagnimandyaand Srotordha. Therefore drug possessing VataKaphaghna, Dipana, Pachana \&Srotoso Dhaka properties are indicated in sthoulya. All the Ingredients of TrushanadiChurahas mainly Kațu, Tikta,Kașhaya Rasa, Laghu,
Rukșha, Tikṣhṇa, UșhṇaVirya, and KaphavatashamakaMedanashakaproperti es which all have opposite action on Kapha Doșhaas well as Meda Dhatu.

\section{CONCLUSION}

It can be concluded that the Trushaadi Churnais the choice of drugs forthe management of Sthoulya. But this is a single case study hence to prove its efficacy there is needed to conduct a study on large number of patient. 


\section{REFERENCES}

Joshi Y.G., Charak Samhita; Vaidyamitra Prakashan, Sutrasathan 1/43, 2009; 4th Edition,Pg.no. 16.

Joshi Y.G., Charak Samhita; Vaidyamitra Prakashan, Sutrasathan 1/41, 2009; 4th Edition,Pg.no. 15.

K. Park Text book of preventive and social medicine $16^{\text {th }}$ Edition Banarsidas Bhnot Publishers, Jabalpur, 2000

Agnivesha. Charaka Samhita, revised by Charaka and Dridhabala ,English translation by Vaidhya Bhagavan Das, Choukamba Orientalia, Varanasi.Chapter 21 ,Page no:375,Sloka no:3,Edition -2006.

Vagbhata Astanga Samgraha,English ,translation by Pof.Srikantha Murthy, Chaukhambha Orientalia, Varanasi.Chapter24 Sloka no:18-36, Page no:424-425.7th Edition-2003no:5-7, Edition2006

Agnivesha. CharakaSamhita, revised by Charaka and Dridhabala English translation by Prof.Priyavrat Sharma Choukamba Orientalia, Varanasi,Chapter 21, Sloka no: 4-9 Page nol 44.

Vagbhata Astanga Samgraha,English ,translation by Pof.Srikantha Murthy, Chaukhambha Orientalia, Varanasi. Chapter24 Sloka no:18-36, Page no:424425. $7^{\text {th }}$ Edition-2003

Shukla V ,Tripathi $\mathbf{R}$ Charaksamhita; Varanasi Chaukhamba Sanskrit Pratisthan ,AstoninditaAdhyay , Strasthan 21/35,2002; Pg. no.300

Tripathy B, Ashtanga Hrudaya, Varanasi Chaukhambha Sanskrit Pratisthan;2012
Sushrut ,Dosha Dhatu Mala Kshaya Vrudhi Adhaya, In ShastriA ,Sushrut Samhita; Varanasi Chaukhambha Sanskrit Samhita ,2005; Pg.no. 63

Baride J.P., Kikarni A.P. Textbook of community Medicine; 3rd edition Mumbai: Vora Medical Publication, 2006; Pg. no. 497-498

\section{http://www.nfhsindia.org/nfhs4.html.}

Accessed on 6 Feb, 2019.

Dr. Yash Pal Munjal, API text book of medicine, 9th edition- 2012, Mumbai, The Association of Physicians of India, Vol-2, Section-18, Chap no-11, Page no-1275

Trimalla Bhatt, Bruhat Yoga tarangini, Aanandashram mudranalaye, Medoroga Nidanam, Tarang 104/36-39

Aacharya YT, Sushruta Samhita, $5^{\text {th }}$ edition Varanasi; Chaukhamba Surbharati Prakashan, reprint 2007, Page no. 73 